NBER WORKING PAPER SERIES

\title{
VALUING THE GOVERNMENT'S TAX CLAIM \\ ON RISKY CORPORATE ASSETS
}

Saman Majd

Stewart C. Myers

Working Paper No. 1553

\author{
NATIONAL BUREAU OF ECONOMIC RESEARCH \\ 1050 Massachusetts Avenue \\ Cambridge, MA 02138 \\ February 1985
}

An early version of this paper was presented at the NBER Tax Program Meeting, October 1983. We are grateful to Alan Auerbach for helpful comments. The research reported here is part of the NBER's research programs in Taxation and Financial Markets and Monetary Economics and project in Government Budget. Any opinions expressed are those of the authors and not those of the National Bureau of Economic Research. 
NBER Working Paper \#1553

February 1985

\title{
Valuing the Government's Tax Claim \\ on Risky Corporate Assets
}

\begin{abstract}
This paper explores the effects of tax asymmetries on the value of risky capital investments made by corporations. The government's claim on the firm is shown to be equivalent to a portfolio of options on the firm's revenues. The tax law's provisions for carrying tax losses forward and backward are introduced, necessitating a numerical solution for the value of the government's claim. The results show that asymmetric taxation of operating gains and losses can significantly affect the after-tax net present value of corporate investment opportunities.
\end{abstract}

Saman Majd

The Wharton School

University of Pennsylvania

Department of Economics

Philadelphia, PA 19104
Stewart C. Myers

M.I.T.

Sloan School of Management

50 Memorial Drive

Cambridge, MA. 02138 


\section{Introduction}

The corporate tax law is asymmetric in its treatment of operating gains and losses: income is taxed at the statutory tax rate only when positive. Although losses up to the amount of taxes paid in the previous three years qualify for an immediate credit against current taxes, losses in excess of that must be carried forward to be credited against future gains. The 'effective tax rate' on these carry forwards is less than the statutory rate for two reasons: (1) the tax losses expire after fifteen years of carry forward, and (2) carry forwards do not earn interest. $1 /$

Conventional capital budgeting rarely recognises this asymmetry. Tax shields are sometimes discounted at a higher rate to account for the risk of not having sufficient taxable income to make full use of the shields, but as a practical matter any adjustment to the discount rate is just a fudge factor. Since the tax paid is a nonlinear function of income, the tax liability cannot in general be valued by discounting its unconditional expectation at any single risk-adjusted rate. It has the properties of a contingent claim and must be valued accordingly. 
Formal analysis of the impacts of asymmetric taxation is just beginning to appear in the literature. Cooper and Franks [1983] recognise that under asymmetric taxation with carry forward privileges, the firm's tax rate is not exogenous. Using a linear programing framework they analyse the interaction between present and future investment and financing decisions: induced by the tax system. They discuss some of the factors that limit Einancial transactions designed to offset tax losses, and conclude that real investment by corporations can be distorted.

In estimating the marginal tax benefits from interest payments on debt, Cordes and Sheffrin [1983] explicitly account for the possibility that firms may not be able to make full use of their interest tax shields. They discuss some of the provisions of the tax law, other than imperfect offset of operating gains and losses, that can cause the firm's marginal tax rate to differ from the statutory rate. They also provide some interesting estimates of tax loss carry forwards. For example they estimate that the fraction of tax credits accounted for by carry forwards from previous tax years for different industries ranged from 11 to 64 percent in 1976. This suggests that carry forward provisions are important to many firms. 
Galai [1983] extends the contingent claim formulation of the firm's capital structure to include the government's tax claim on the firm. He recognises the option characteristics of the government's tax claim and uses a one-period model without carry privileges to examine the value of debt and equity under both full loss-offset and no loss-offset tax systerns. $2 /$

In their investigation of the hedging policies of firms, Smith and stulz [1983] also note that the government holds a call option on the pre-tax value of the firm. Thus the tax law creates a hedging motive even for widely-held corporations.

The public finance literature has long recognised the asymmetry in the tax system. In their classic paper, Domar and Musgrave [1944] analyse the effect of imperfect loss-offsets on risk-taking by individuals. Using the 'expected loss' (i.e., the expectation of negative returns) as the measure of risk, they conclude that proportional taxation can reduce risk-taking in the absence of full loss-offsets. (They also examined the case of known and constant partial loss-offset with similar conclusions.) ${ }^{3 /}$ More recently, Green and Talmor [1983] formulate the government's tax claim as a call option and, using a one-period model without carry privileges, analyse the 
effect of the asymmetry on corporate risk-bearing.

Much of this literature has used effective tax rates (defined as the ratio of post- and pre-tax internal rates of return) as a measure of the tax burden on investment. ${ }^{4 /}$ For example, Hulten and Robertson. [1983] report that asymmetric taxation causes differences in the effective tax rates on risky assets. However, internal rates of return (IRRs) have no meaning for contingent claims, so these effective tax rates make little sense. Since investment decisions are for should bel made on the basis of present values, evaluation of tax burdens should also be based on present values.

Although Auerbach [1982] supports the use of such effective tax rates in evaluating tax neutrality, he points out (in Auerbach [1981]) that when effective tax rates are state dependent (e.g.) because of asymmetric taxation of gains and losses), the simple expectation of the effective tax rates across states is an inappropriate measure of the tax burden. An additional adjustment for risk is required, and he proposes using a "risk adjusted effective tax rate". But risk adjusted IRRs are not much better than unadjusted ones, and we are back to the problem of calculating the impact of the asymmetry on present values.

Auerbach ([1983a] and [1983b]) has also studied the effects of tax asymmetries on firms' short- and long-term 
investment incentives. We discuss these papers in section 5, but mention here that he concludes that real investment can be distorted. Specifically, he concludes that carry forwards can lead to over-investment by firms with a surplus of tax losses.

None of the papers referred to develops a general procedure for calculating the impact of tax law asymetry on the after-tax values of real assets. Such a procedure would be a valuable aid to managers making capital budgeting decisions. It would also allow us to ask some interesting questions about tax policy. For example, the Tax Equity and Reform Act of 1982 more than doubled the carry forward period from seven to fifteen years. At first glance this seems very generous, but it is hard to evaluate just how generous it is without knowing how to calculate its impact on present values.

The next two sections show how option pricing concepts can be applied to value the government's tax claim on risky assets. Since no closed-form option pricing formulas apply, values must be compited by numerical methods. Section 4 describes our calculations in more detail and presents after-tax values for a reasonably realistic 'standard project under various assumptions about project profitability, risk and the tax position of the firm owning 
it. Section 5 investigates the interaction between the new project and the existing assets of the firm, and section 6 offers some concluding comments.

\section{Taxes As Contingent Claims}

In the absence of tax loss carry backs or carry forwards, the government's tax claim is equivalent to a portfolio of European call options, one on each year's operating cash flow. The heavy line in Figure 1 shows taxes paid as a function of taxable income in a given year, and has the same shape as a call option's payoff at exercise.

This option payoff function also describes the taxes paid on the income of a stand-alone project (i.e., taxes paid by a firm undertaking only one project). But in general the taxes paid on a project's income depend on the tax position of the firm owning it. Suppose the project is owned by IBM. It seems safe to say that IBM will not have tax loss carry forwards at any time in the foreseeable future, and will pay taxes at the margin at the full statutory rate. Thus, any project losses can be offset against IBM's other income. The tax system is symmetrical for IBM when it considers an incremental capital investment project. 
We can express these option analogies more formally. Consider a project that is the firm's only asset. Let the pre-tax operating cash flow and depreciation allowance at time $t$ be $y_{t}$ and $d_{t}$. respectively. Ignore for now the investment tax credit (ITC), and assume that the project is all equity financed. In the absence of tax loss carry forwards or carry backs, the project's after-tax cash flow at time $t$ is:

$$
q=y_{t}(1-t)+t d_{t}-\max \left[t\left(d_{t}-y_{t}\right), 0\right]
$$

The first two terms are the cash flow under a system of symmetrical taxation (such as IBM effectively enjoys on marginal projects). The additional term represents the effect of the asymmetry: the government has a put option on the operating cash flow.

We can rewrite this as:

$$
c_{t}=y_{t}-\tau \max \left[y_{t}-d_{t^{\prime}} 0\right]
$$

The after-tax cash flow is the difference between the pre-tax operating cash flow and the government's claim on it. The government's claim is equivalent to $\tau$ European call options on the operating cash flow with exercise price equal to the depreciation allowance.

since the government taxes the firm's total income, the 
incremental impact of a new project on the value of the firm will depend on the operating cash flows of the firm's existing assets and on their correlation with those of the project. The after-tax cash flow for the firm with the new project will be:

$$
c_{t}=\left(y_{t}+z_{t}\right)-\tau \max \left[\left(y_{t}+z_{t}\right)-\left(d_{t}+d_{z t}\right), 0\right],
$$

where $z_{t}$ is the operating cash flow and $d_{z t}$ the depreciation allowances for the firm without the new project. Because the government's claim is an option, the value of the tax claim on the sum of $y_{t}$ and $z_{t}$ is not the sum of the values of the tax claims on each taken separately. Hence value additivity does not hold strictly.

Tax carry privileges do not change the shape of the contingent tax payment drawn in Figure 1. But the firm does not begin paying taxes until that year's taxable income exceeds cumulative tax losses carried forward from up to fifteen previous years. In other words, the vertical dividing line shifts to the right. Carry backs shift the horizontal dividing line down from zero by the sum of taxes paid over the last three years.

Again we can state this formally. Consider the case of unlimited carry forwards (but without any carry backs). The tax loss carried forward to time $t$ from the previous period 
is:

$$
\lambda_{t-1}=\max \left[\lambda_{t-1}+d_{t-1}-y_{t-1}, 0\right]
$$

The carry forward depends on the carry forward in the previous period which in turn depends on the still-earlier carry forward, and so on. The carry forward at the beginning of the project (time zero) is given. The after-tax cash flow becomes:

$$
c_{t}=y_{t}-\tau \max \left[y_{t}-d_{t}-\lambda_{t} 0\right]
$$

Since $\lambda_{t}$ depends on all realised incomes prior to time $t$, the payoff to the government (i.e., the tax paid) also depends on the realised incomes. It is straight forward to introduce the ITC and carry backs, and to limit the length of time allowed for carry forwards.

Thus carry privileges do not break the correspondence between the government's tax claims and a series of call options. But the carry privileges rule out use of any closed-form option pricing formulas, because any particular year's tax payment to the government depends on the sequence of income for up to fifteen prior years. The payments are path-dependent, and numerical methods are required to value them. We discuss these methods in the next section.

Note, however, that the rules for computing taxes are 
exogenous. Future tax payments are always unknown, but there are no decisions to be made about taxes. If the firm has the opportunity to use carry backs or carry forwards, it does so at the first opportunity. 5/ As far as taxes and carry privileges are concerned, the firm faces only an event tree, not a decision tree.

However, the future tax position of the firm can affect the future operating cash flows. Our numerical procedure must take project and firm cash flows as exogenous. We do not consider whether a future tax loss on a project undertaken today will affect future investment decisions. We also rule out cases in which today's project is managed differently, depending on its (or the firm's) tax position. This is undoubtedly unrealistic. For example, an otherwise profitable firm might find it less painful to stick with a losing project than a firm already surfeited with carry forwards. or the profitable firm might sell the losing project in order to establish an immediate tax loss, for the same reason that investors in securities often find it worthwhile to realise capital losses before the end of the tax year.6/

This, however, is just one of many ways a firm can compensate for tax asymmetries. Four additonal examples are: (1) The firm may change its accounting policies to 
shift taxable income over time; (2) The firm may seek to acquire another firm that has taxable income; (3) The firm may choose to 'sell' its tax shields to another firm by means of a leasing arrangement; (4) The firm may issue equity and buy bonds in order to generate taxable income. $7 /$ These transactions are not costless, however, and in many cases fall far short of exhausting the entire tax loss.

Our analysis, since it assumes operating cash flows are exogenous, gives a lower bound on after-tax project value. It also shows the potential gain from financing or investment decisions which shift taxes over time or between firms. We do not analyse these tax-shifting decisions specifically.

\section{Valuing The Government's claim on The Project}

This section describes the numerical procedure used to calculate the present value of the taxes paid on a risky project. Our discussion will be restricted to finding the present value of the taxes paid on the operating cash flow in year $t, y_{t}$, in the presence of unlimited carry forwards. The present value of the taxes paid on the stream of operating cash flows is simply the sum of the values of the claims on each future year's operating income. Extension of 
the procedure to include carry backs and to limit the carry forward period is straightforward. The value of the government's claim on $y_{t}$ will depend on the distribution of the carry forward at $t$, which in turn depends on the realised values of the prior income. To see how this path dependency complicates the solution to this problem, consider the Cox-Ross technique for ỵaluing options: If the payoff to the option can be replicated by a portfolio strategy using traded securities, the present value of tree option is the expected payoff (conditional on the current values of the relevant state variables) discounted at the risk free rate. $8 /$ In other words, the option can be valued as if both it and the underlying asset are traded in a risk neutral world. The difficulty here is in deriving a closed-form solution for the expected payoff conditional on the realisations of income between now and the payoff date.

When closed-form solutions do not exist, the alternative is to solve the problem numerically. Path dependencies can make some numerical techniques cumbersome. However, our problem has features that allow us to employ a simple Monte Carlo simulation technique to approximate the distribution of the payoff conditional on the prior sequence of operating cash flow. $9 /$ The rule determining the carry forward at any time (the path dependent feature in this problem) is specifled exogenously, and depends only on past realisations 
of the operating cash flow. Hence, although future tax payments are always uncertain, the rules for determining them (once the cash flows are known) are not. The Monte Carlo simulation technique exploits this feature of the problem by simulating the sequence of operating cash flow up to the payoff date. Each time a value is generated from the distribution of an operating cash flow, the tax liability and the carry forward to the next period are completely determined.

The simulation must also update the distributions of future operating cash flows every time a value is generated. Different assumptions about the stochastic process generating the time series of operating cash flow are possible. In the calculations reported in the next section, we break down operating cash flow into two components:

operating cash flow = net revenues - fixed costs,

$$
y_{t}=x_{t}-F,
$$

where 'net revenues' means revenues less variable costs. We assume $F$ is known with certainty, and that the stochastic processes generating each year's net revenue are perfectly correlated lognormal diffusions. $10 /$ That is, the forecast error in any one year's net revenue causes the same 
proportional change in the expectations of all future net revenues, and the same proportional change in the present value of each year's future net revenues. If this assumption seems unduly restrictive, note that it is the usual justification for using a single risk-adjusted rate to discount a stream of cash flows. Thus it implicitly underlies standard practice. ${ }^{11 /}$

By generating a large number of simulated cash flows, an aproximate distribution for the government's tax payment in each year is obtained. The expected value is computed and discounted at the riskless rate to obtain the present value of the payment. The present value of the government's claim on the project is the sum of the present values of the claims on individual cash flows.

\section{Numerical Results For The Standard Project}

This section describes the valuation of a standard project under a variety of assumptions about profitability and risk. The incremental impact of the project on the value of the firm depends on the operating cash flows of the firm. In particular, it depends on their level and on their correlation with those of the new project. In the next section we model the existing assets of the firm explicitly 
and investigate the combined impact of profitability and correlation. In this section we focus on the new project, and examine the impact of existing assets only in two extreme cases.

The pre-tax cash flows of the standard project are described in Table 1. We assume the project costs $\$ 100$ at $t$ $=0$. Its expected net revenues (revenues net of variable costs) decay at a constant rate $\delta$, until expected net revenues equal fixed costs $F$, when the project expires. ${ }^{12 /}$ There is no salvage value.

The base-case project parameters are shown at the bottom of the Table. Pre-tax NPV $=0$ when initial net revenue is $x_{1}=29.53$. Note that fixed costs are discounted separately at the risk-free rate $r_{f}$.

The discount rates $r$ and $r_{f}$ are expected real rates of return demanded by equity investors. They are calculated without deducting any personal income taxes.

Suppose the project is owned by Penn Central, or some other firm with such large tax loss carry forwards that we may assume a zero effective tax rate on new projects. We will use 'Penn Central' or 'PC' as a label for the extreme case when the firm does not pay taxes. For Penn Central, pre-tax and after-tax NPV are the same. 
At the other extreme, we can imagine the standard project undertaken by a firm that is sure to pay taxes at the margin at the full statutory rate $\tau=0.46$. We label this case 'IBM'. There are no tax asymmetries on incremental projects undertaken by IBM. Thus, the after-tax value of the standard project is:

$$
\operatorname{NPV}(\text { IBM })=-100+\frac{\operatorname{ITC}}{\left(1+r_{f}\right)(1+1)}+\sum_{t=1}^{T} \frac{\tau d_{t}}{1\left[\left(1+r_{f}\right)(1+1)\right]}+\sum_{t=1(1+r)^{t}}^{T} \frac{x_{t}(1-\tau)}{t=1} \sum_{t=1\left(1+r_{f}\right)}^{T} j_{t}
$$

where ITC is the investment tax credit and $d_{t}$ the tax depreciation (in dollars) in year $t$. We use the 5-year ACRS schedule, so that $d_{t}=0$ for $t>5$. Since ITC and $d_{t}$ are safe nominal flows, they should be discounted at a safe nominal rate, $\left(1+r_{f}\right)(1+i)-1$, where $i$ is expected inflation. However, we set $i=0$ for the calculations shown below. $13 /$ Note that we have used the pretax safe nominal rate to discount the safe flows. A strong case can be made for discounting depreciation tax shields, and possibly the fixed costs as well, at the after-corporate-tax nominal riskless rate. Ruback [1983] shows that the appropriate discount rate for riskless cash flows is the after-tax riskless rate. His argument is based on a hedging strategy undertaken by the firm: by adjusting its portfolio of riskless bonds, the firm can exactly offset any future riskless cash flow. If the firm can make full use of its interest tax shields, this strategy implies that the 
discount rate to be used for safe cash flows is the after-tax riskless rate.

Note, also, that the same rate $r$ is use to discount both before-tax and after-tax net revenues. Since $x_{t}(1-\tau)$ is a constant proportion of $x_{t}$, the present value of $x_{t}(1-\tau)$ must always equal $(1-\tau)$ times the present value of $x_{t}$.

The project's values to Penn Central and IBM provide two extreme cases. Our third case occurs when the firm and the project are one and the same. Tax asymmetries have their maximum impact for stand-alone projects. of course, carry backs and carry forwards mitigate the effects of the asymmetry. We examine the stand-alone project under different assumptions about tax loss carry provisions: (1) no carry provisions, (2) unlimited carry forwards but no carry backs, and (3) three-year carry backs and fifteen-year carry forwards (i.e., the current system). We label them 'PROJ', 'PROJC', and 'PROJFB' respectively.

Table 2 shows after-tax NPVs for the standard project, calculated for several levels of profitability (measured by $x_{1}$ ). The first panel of the Table reports results for the base case. The NPVs for Penn Central (PC) are pre-tax project values, and those for IBM are project values under full loss-offset. The NPVs for PROJFB are project values for the stand-alone project under the current provisions for 
carrying tax losses. The differences between the NPVs for IBM and the stand-alone project without any carry privileges (PROJ) show the maximum impact of tax asymnetries. The NPVs for PROJC show the maximum extent that unlimited carry forwards can mitigate the impact of tax asymmetries for the stand-alone project.

The other panels in Table 2 report NPVs under different assumptions about project risk and project life. The relations between these NPVs are more easily seen in Figures $2,3,4,5$, and 6 . Figure 2 simply plots the numbers given in the first panel of Table 2. Figures 3 and 4 show how the NPVs change when the standard deviation of the rate of change of present value of net revenue, $\sigma_{;}$is raised or lowered from the base case. ${ }^{14 /}$ Figures 5 and 6 show how the NPVs change when the project life is increased and decreased (the rate of decay of net revenues, $\delta$, is also changed to be consistent with the project life).

These numerical results establish that tax asymmetries can have a substantial impact on after-tax project NPV. However, the extent of the impact depends on project risk and on whether carry provisions apply. In Figure 2, for the base case, tax asymmetries reduce project present value by about one fifth of required investment. For example, compare NPV(IBM) and NPV(PROJ) at the breakeven point where 
pre-tax NPV $=0$. Introducing unlimited tax loss carry forwards cuts the asymmetry's impact on value about in half. For low risk projects (see Figure 3 , where $\sigma=0.05$ ) the impact of tax asymmetries is somewhat reduced with no carry, but essentially eliminated with unlimited carry forwards. Increased project risk (see Figure 4, where $\sigma=$ 0.45) increases the impact of tax asymetries, and carry forwards are little help.

Under the current system of three-year carry backs and fifteen-year carry forwards, the carry back provision seems to be more valuable. For example, compare the curves for PROJC and PROJFB: in all cases the project is more valuable with carry backs and limited carry forwards than with unlinited carry forwards but no carry backs. This is true even when the project life is extended to 30 years (Figure 6). The carry backs are more valuable because, to the extent that the firm uses them, it faces loss-offset at the statutory rate. Hence carry backs are not subject to the same penalties as carry forwards.

of course the simulations could be repeated for endless combinations of assumptions about project life, cash flow patterns, discount rates, etc., but Figures $2,3,4,5$, and 6 establish that tax asymmetries are a first-order problem.

We would like to have a tax system under which all firms 
value the same investment in the same way. Our results indicate that tax asymmetries may be a more important distortion than the firm's current tax position. For example, IBM and Penn Central would calculate similar values for projects with zero, or moderately positive, pre-tax NPVs. Penn Central's advantage over IBM increases for nighly profitable projects, but this would not be too serious since good projects would be accepted by either firm. However, stand-alone projects always have lower after-tax NPV than the same project taken by either Penn Central or IBM, even when carry backs and carry forwards are allowed. It appears that undiversified firms, or projects forced to stand alone, are at a significant tax disadvantage. This disadvantage is particularly severe for high-risk assets.

It is difficult to express these results in terms of any 'effective tax rate'. Internal rates of return have no meaning for assets with contingent payoffs, so ratios of post-tax to pre-tax rates of return make no sense. However, Figure 7 shows the ratio of the present value of the government's tax claim to the pre-tax present value (not NPV) of the base case project described in Table 1: This ratio switches from negative to positive for IBM as profitability increases, and is always positive for the stand-alone project. Although Figure 5 does not show it 
clearly, the stand-alone project's 'tax ratio' approaches IBM's tax ratio as project profitability becomes very large, both approaching $\tau=0.46$.

This ratio may be interesting, but it is an inadequate guide when we think about tax policy. What matters for tax policy is whether the tax system changes investment decisions. For that question, it is more useful to examine pre- and post-tax NPVs.

5. Extending the Simple Model

5.1. Modelling the Eirm's Existing Assets Explicitly

The calculations reported above represent some extreme cases. For example, we did not distinguish between 'large' and 'small' projects. For small projects, the firm's future tax position is exogenous: whether or not the firm gays taxes in any period depends entirely on the performance of the existing assets. The Penn Central and IBM examples effectively assumed the standard project to be small. Large projects are those whose performance affects the overall tax status of the firm. Here the stand-alone project is the extreme case. 
But there are many interesting cases between these extremes. In general, the impact of the new project will depend on the combined effects of the size and profitability of existing assets, as well as on the correlation between them and the new project. By modelling the existing assets explicitly, we can make the future tax status of the firm endogenous (i.e., to depend on the performance of both the project and the existing assets). In this section this is accomplished by simulating the operating cash flows of the existing assets together with those of the standard project.

Imagine the firm having reached a steady state level of investment in its existing business. Each year the firm invests in a unit that is expected to produce level annual operating cash flows for fifteen years, after which it expires worthless. Although the net revenue from each unit is uncertain, all units produce identical cash flows in any period. $15 /$ We assume, as in the case of the standard project above, that the net revenues are generated by perfectly correlated lognormal diffusions.

As before, we take project and firm cash flows as exogenous, and do not consider cases where future investment decisions may change as a result of changes in the firm's tax position. For example, we ignore the option to forego 
investment in a new unit in any year, and assume the firm is committed to its steady state level of investment. This assumption is likely to be most questionable in the case of a new project that is 'large' relative to the existing assets.

Because of the known investment in a new unit each year, the firm receives a known and constant total depreciation allowance and ITC each year. Table 3 summarises the characteristics of the firm's existing assets, and gives the base-case values for the parameters. The new project to be added to the existing assets of the firm is the standard project described in section 4 (see Table 1), and has net revenues that are correlated with those of the existing assets.

Our simulations require a finite horizon, whereas we view the firm's existing business as a (stochastic) steady state perpetuity. We choose a terminal horizon at 60 years; even though we assume unlimited carry forwards. Given our assumption of exogenous pre-tax cash flows, the impact of a 15-year new project on the tax position of the firm in year 15 will almost certainly be negligable by the end of 60 years.

Table 4 shows how the incremental value of the new project depends on the relative profitabilities of the 
project and existing assets. The first column of entries gives the net present value of the stand-alone project for different levels of profitability. As before, the project's profitability is measured by its expected initial net revenue, $x_{1}$. The marginal impact of the new project on the value of the firm is presented for different levels of the firm's profitability (measured by the expected annual operating cash flow per unit, Y). We compute the value of the project as the difference between the present value of the firm's assets with and without the project, less the cost of aquiring it (this is labeled 'NPV(COMBINED)' ). The three panels in Table 4 show the effect of varying the correlation between the new project and the existing assets.

The results for the case $\rho=0$ are displayed in Figure 8. The incremental value of the project is plotted as a function of its profitability for three different levels of profitability of existing assets. Also plotted is the net present value of the project when stand-alone (with unlimited carry forwards).

Again we see that tax asymmetries have a significant impact on project value, even when unlimited carry forwards are allowed. As Figure 6 shows, the project is always more valuable to a firm that has other assets, although the 
difference in value depends on their relative profitabilities. For example, a very unprofitable project (e.g., $\left.x_{1}=20\right)$ has the same value stand-alone as when combined with low-profitability assets $(Y=100)$. In the limit of low firm and project profitability, the addition of the project does not change the tax position of the firm, and it continues to be untaxed at the margin. However the same project is more valuable to a very profitable firm ( $Y=1000)$ because the project's losses will shield some of the firm's gains. The extra value is in part due to the increase in present value of the project's depreciation tax shields, and in part due to the ability to deduct operating losses.

As the profitability of the project is increased, both its stand-alone value and its value when combined with other assets increase. But the difference between its value to the very profitable firm and relatively unprofitable firm diminishes. That is, the curves marked ' $Y=100$ ' and ' $Y=1000^{\prime}$ in Figure 6 approach each other as $x_{1}$ increases. The project is now beginning to show some gains, so there are fewer losses to shield the profitable firm's gains. The unprofitable firm's losses can now be used to shield the project's gains. Hence the value of the project to the unprofitable firm increases relative to its value to the profitable firm. At approximately $x_{1}=32$, the value of the project to the two firms is equal. 
As the project becomes very profitable $\left(e . g ., x_{1}=50\right)$ its stand-alone value approaches its value to the very profitable firm $(y=1000)$. In this limit, the project does not change the tax position of the firm, and it continues to be fully taxed at the margin. The project is now most valuable to the unprofitable firm because the project.gains can be used to shield some of the firm's losses.

of course the strength of these effects depends on the covariance between project and firm cash flows. As Tables 4 and 5 show, the value of a given project to a firm that has other assets increases with decreasing correlation between them (i.e., diversification helps).

\subsection{Intertemporal Effects of Carry Forwards}

The assumption that the distributions of pre-tax cash flows are exogenous ignores some interesting intertemporal effects of carry forward provisions. The firm has an incentive to use its carry forwards as soon as possible, but some of the ways in which it can do so also alter the future pre-tax cash flow distributions. In particular, the change in the firm's future investment policy due to its level of carry forwards will make future cash flow distributions endogenous . 
Auerbach [1983a] examines the effect of carry forwards on the steady state level of investment by the firm. He interprets the asymmetry as a way for the government to avoid subsidising poorly performing firms. ${ }^{16 /}$ Carry forwards are thus a way of allowing firms that invest in risky assets and occasionally have a bad year to obtain some benefit from their tax shields. But although imperfect loss offsets discourage inefficient firms from investing exante, once such a firm has accumulated carry forwards it has an incentive to overinvest in order to use them up.

In Auerbach's model, the firm receives a one-period investment opportunity each period. In deciding whether or not to invest in the current opportunity, the firm must consider how the investment changes the value of future opportunities through its effect on future carry forwards. Hence carry forwards couple current and future investment opportunities, and the firm must solve a stochastic dynamic program that is made difficult by the complicated stochastic process for the carry forwards. He uses simulation to solve for the firm's steady state probability of investment, and finds that inefficient firms indeed have an incentive to overinvest relative to efficient ones. Auerbach [1983b] also deals with this issue. He fits a simple first-order process to the level of carry forwards reported by firms and calculates the long run distribution for carry forwards. He 
finds that inefficient firms indeed have an incentive to overinvest relative to efficient ones. Auerbach [1983b] also deals with this issue. He fits a simple first-order process to the level of carry forwards reported by firms and calculates the long run distribution for carry forwards. He integrates this numerically to derive the conditional probability of a tax loss in any given year. Then, by assuming a given pre-tax IRR, he uses these probabilities to obtain expected tax payments, the expected after tax IRR, and the effective tax rate. He finds that, depending on the recent earnings history of the firm, the asymmetry can raise or lower the effective tax rate on new investment by the firm.

Finally, Cooper and Franks [1983] explicitly include the effect of the asymmetries on future investment and financing decisions in their linear programing model. Thus they capture both the effect of the current tax position on future decisions and the interaction of investment and financing decisions. However, their procedure is difficult to apply in practical capital budgeting situations.

6. Conciusions 
This paper examines the impact of asymmetric taxation of operating gains and losses on the value of new investment by corporations. The government's tax claim on the firm is modeled as a series of contingent claims on the pre-tax cash flows of the firm. Assuming that the distributions of pre-tax cash flows are exogenous, a simulation procedure is used to arrive at the distributions of after-tax cash flows. The Cox-Ross risk neutrality argument is then invoked to find the present value of the government's tax claim on the pre-tax cash flows.

The assumption that the distributions of pre-tax cash flows are exogenous and independent of the future tax position of the firm is important in our analysis. Although it precludes analysis of the intertemporal effects of the tax asymmetries described above, it allows us to use the simulation procedure to approximate the distributions of after-tax cash flows. Since the distributions of future carry forwards and carry backs depend on the entire sequence of pre-tax cash flows, simulation allows us to value the government's tax claim under the actual provisions for carrying tax losses forward and back.

Our calculations show that tax asymmetries can have a significant impact on project values, even when carry forwards and carry backs are allowed. This distortion is 
particularly severe for high risk assets that stand alone or that are part of an undiversified firm. Many large scale energy projects fit this description. The procedure presented in this paper allows us to calculate after tax values for such projects, and is therefore useful in many capital budgeting problems.

We have not formally addressed issues of public policy arising from asymetric taxation. Further research will include analysing more realistic projects in order to better understand the effects of tax asymmetries on project values and investment decisions. We will then be in a better position to address the issues of public policy.

Apart from diversification within the firm, we did not explicitly analyse other transactions designed to offset tax losses. However, the magnitude of the impact of the asymmetry on asset value can be interpreted as an estimate of the value of pursuing these costly tax-motivated transactions.

The procedure for calculating after-tax project value can also be applied to valuation of the firm under regulation. Since the allowed rate of return is a maximum allowed return, the government "taxes" any return above that. Hence the government's claim on the regulated firm is similar to the tax claim on the firm without carry 
privileges. Of course this simple analogy ignores important features of the regulatory process, but it can easily be adapted to handle more realistic cases. The key assumption remains that the pre-regulation cash flows are exogenous. 
FOOTNOTES

1. Also, since losses are carried forward in nominal terms, inflation further reduces the value of carry forwards.

2. Brennan and Schwartz [1978] also explicitly account for the risk of interest tax shields in their analysis of the optimal capital structure problem. However, they focus on the risk of losing the tax shields due to bankruptcy, rather than the risk due to having insufficient operating income.

3. See also Atkinson and Stiglitz [1980], chapter 4, and Stiglitz [1969].

4. For example, see Auerbach [1982]. Iike most of the literature dealing with this problem, he uses the Hall-Jorgenson "user cost of capital" model.

5. Since the value of a call option is convex in the exercise price (see Merton [1973]), and no interest is paid on carry forwards, it is always optimal to use tax losses as soon as possible.

6. Constantinedes [1983] sets forth the conditions for a tax-paying entity to realise tax losses immediately and to defer gains as long as possible.

7. Issuing equity to buy bonds will only be effective under certain assumptions about debt and taxes. See Cooper and Franks 1983 for a discussion of some of the financial transactions designed to exploit the firm's tax losses.

8. See Cox and Ross [1976] for a discussion of this technique. Brennan [1979] discusses alternative conditions under which such a 'risk-neutral' valuation procedure is valid. One result is that options can be valued by such procedures in the traditional framework of the Capital Asset Pricing Model provided that asset returns are multivariate normal and that there is a representative investor who exhibits constant absolute risk aversion. See also Rubinstein.[1976]. 
9. Boyle [1977] first used a Monte Carlo simulation technique to value a European call option on a dividend-paying stock.

10. Remember that, to use the risk-neutrality technique, we must value the option as if both it and the underlying asset are priced in a risk neutral economy. Hence the diffusions generating the present values of net revenues have an expected return equal to the riskless rate.

11. See Myers and Turnbull [1977] and Fama [1977].

12. This is not realistic, as project life is generally endogenous to the valuation procedure. See Myers and Majd [1983].

13. Inflation reduces the present value of nominal flows such as depreciation tax shields. Also, carry forwards are fixed in nominal terms. Hence, inflation reduces the exercise price of the government's options on the stand-alone project's operating cash flows. Incorporating the effects of inflation in the simulations is generally complex. For example, we would have to model the stochastic interaction between inflation and project revenues. However, to obtain a simple measure of the effect of inflation, we $r$ an the base case with an inflation rate of 88 , assuming no correlation between it and project revenues. The present value of the project to IBM was reduced by about 10 for any level of profitability. The present value of the stand-alone project was reduced by much less, but the effect increased with higher levels of profitability.

14. We hold constant the discount rate used to calculate the present values of pre-tax net revenues despite the shift in $\sigma$. This assumes the shifts in risk affect diversifiable risk only. We do this to make comparisons of Figures 2,3 and 4 easier. Adjustments to discount rates would not change our qualitative conclusions about the effect of tax asymmetries.

15. This does not rule out the possibility of diversification within the firm. Diversification within each unit will be reflected in $\sigma_{Y}$.

16. This is not the only possible view. Atkinson and stiglitz [1980, p.115] suggest that limited loss offsets are a way for the government to distinguish between investment and consumption activities. 
Investment activities are interpreted as those that make a profit (and are activities as those that make subsidised). The two views mutually exclusive.

taxed) and consumption a loss land are not are, of course, not 


\section{REFERENCES}

Atkinson, A., and J. Stiglitz, 1980, Lectures on Pubilic Economics, McGraw-Hill, Inc.

Auerbach, A., 1981, "Evaluating the Taxation of Risky Assets", NBER Working Paper \$806.

Auerbach, A., 1982, "Tax Neutrality and the Social Discount Rate", Journal of Public Economics, 355-372.

Auerbach, A., 1983(a), The Dynamic Effects of Tax Law Asymmetries", NBER Working Paper \$1152.

Auerbach, A., 1983(b), "Corporate Taxation in the U.S.", mimeo.

Boyle; P., 1977, "Options: A Monte Carlo Approach", Jourinal of Financial Economics, 323-338.

Brennan, M., 1979, "The Pricing of Contingent claims in Discrete Time Models", Journal of Finance, 53-68.

Brennan, M., and E.Schwartz, 1978, "Corporate Income Taxes, Valuation, and the Problem of optimal Capital structure", Journal ôf Business, Vol.51, No.1, 103-114.

Constantinedes, G., 1983, "Capital Market Equilibrium with Personal Tax", Econometricià, 611-636.

Cooper, I., and J.Franks, 1983, "The Interaction of Financing and Investment Decisions when the Firm Has Unused Tax Credits", Journal of Finance, 571-583.

Cordes, J., and S. Sheffrin, 1983, "Estimating the Tax Advantage of Corporate Debt", journal of Finance, 95-105.

Cox, J., and S. Ross, 1976, "The Valuation of Options for Alternative stochastic Processes", Journài óf Financial Economics, 145-166. 
Domar, E., and R. Musgrave, 1944,. "Proportional Income Taxation and Risk-Taking", Quarterly journal of Economics, p. 288-422.

Fama, E., 1977, "Risk Adjusted Discount Rates and Capital Budgeting Under Uncertainty", Journal of Financial Economics, 3-24.

Galai, D., 1983, Corporate Income Taxes and the Valuation of Claims on the Corporation", UCLA Working Paper $\$ 9-83$.

Green, R.C., and E.Talmor, 1983, "On The structure and Incentive Effects of Tax Liabilities", Carnegie-Melion University Working Paper \#1-83-84.

Hall, R., and D. Jorgenson, 1967, "Tax Policy and Investment Behaviour", Amerícan Economic Revieww, Vol. 57, No. 3.

Hulten, C., and J. Robertson, 1983, "The Taxation of High Technology Industries", The Urban Institute (Wash. D.C.) Discussion Paper \#3306-01.

Merton, R.C., 1973, "Theory of Rational Option Pricing", Bell Journal of Economics and Management Science, 141-183.

Myers, S., and S. Turnbull, 1977, "Capital Budgeting and the Capital Asset Pricing Model: Good News and Bad News", Journai of Financé, 321-333.

Myers, S., and S. Majd, 1983, "Calculating Abandonment Value Using Option Pricing Theory", Sloan School of Management, MIT Working Paper \#I462-83.

Ruback, R., 1983, "Calculating the Present Value of Riskless Cash Flows", Sloan School of Management, MIT Working Paper \$1348-83.

Rubinstein, M., 1976, "The Valuation of Uncertain Income Streams and the Pricing of Options", Beil journal of Economics, 407-425.

Smith, C., and R. Stulz, 1983, "The Determinants of Firm's Hedging Policies", University of Rochester Working Paper AMERC 83-15.

Stiglitz, J., 1969," "Effects of Wealth, Income, and Capital Gains Taxation on Risk-Taking", Quarteriy Journai of Economics, 263-283. 


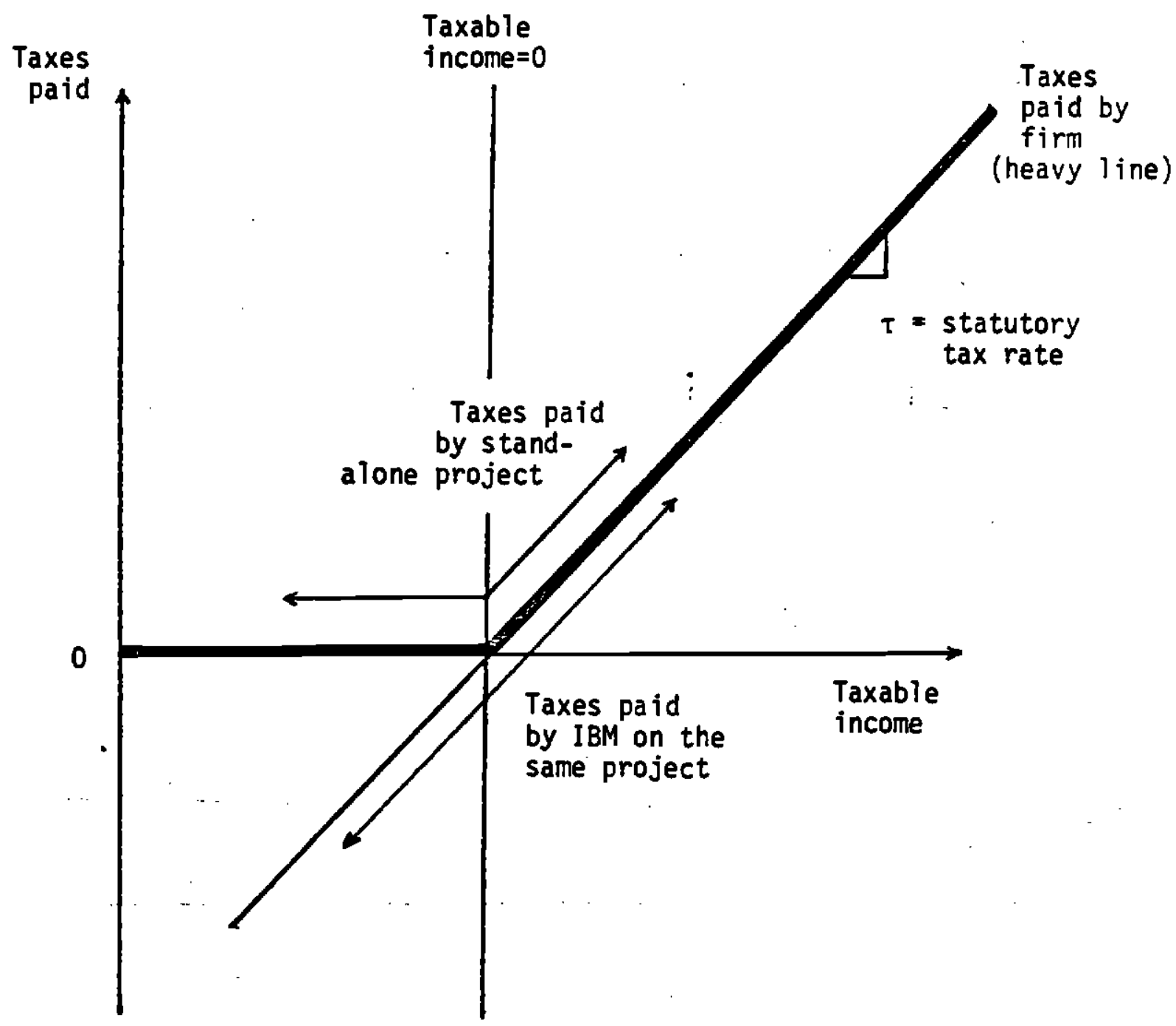

Figure 1. Taxes paid as a function of taxable income. 
Table 1: The Standard Project

\section{Cash flows}

\section{Expected}

pre-tax

cash flows

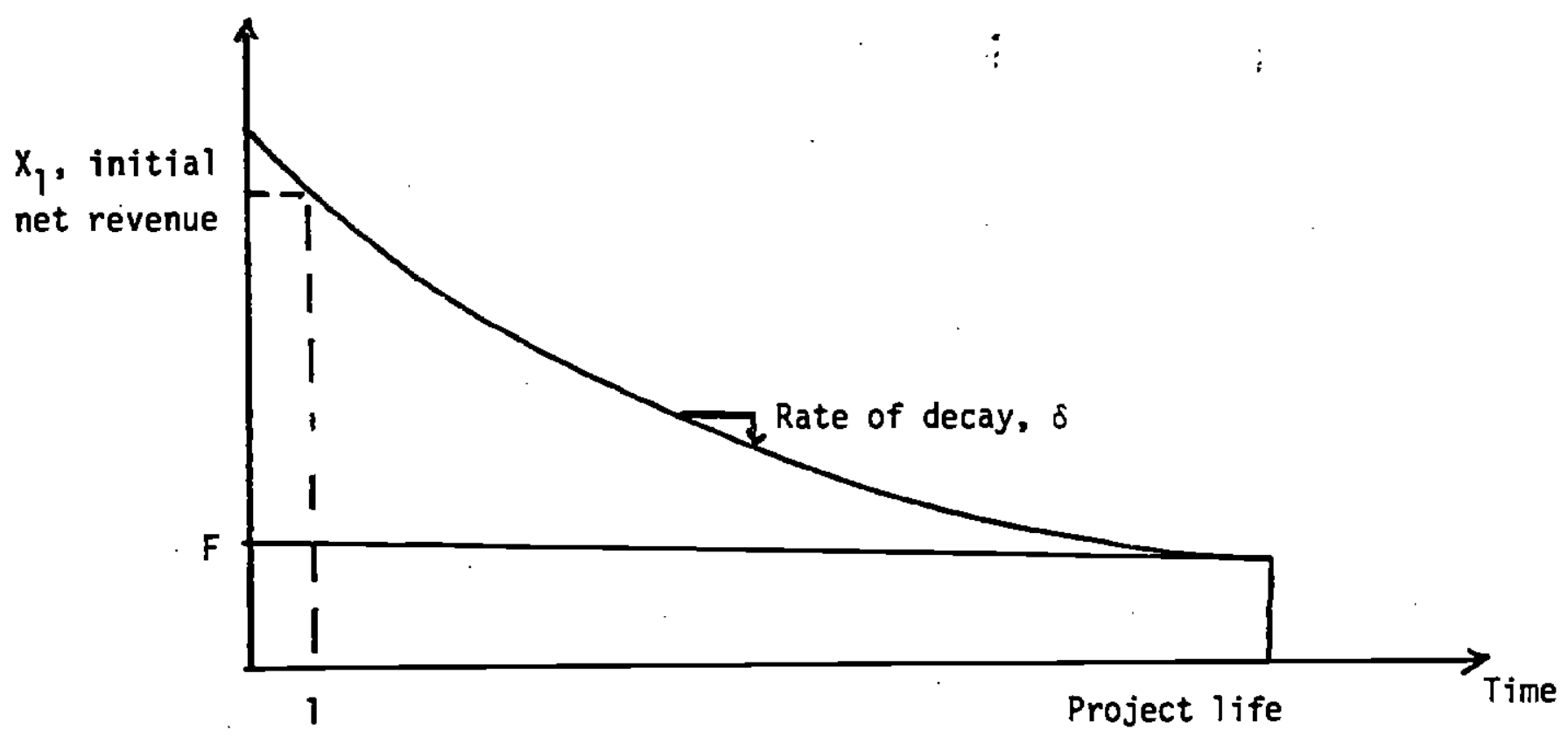

$$
\begin{aligned}
& \text { cash flow }=\text { revenue }-\underset{\text { variable }}{\text { cost }}-\begin{array}{c}
\text { fixed } \\
\text { cost }
\end{array} \\
& x_{t}=\text { revenue }- \text { variable cost } \\
& F=\text { fixed cost } \\
& r=\text { opportunity cost of capital for } x_{t} \\
& r_{f}=\text { risk-free rate } \\
& \sigma=\text { standard deviation of the rate of change of the present value } \\
& \text { of future } x_{t}{ }^{\prime} s \\
& \delta \text { = decay rate of } x_{t}
\end{aligned}
$$

$\underset{\substack{\text { Pife } \\ \text { Project }}}{\operatorname{time} \text { at which forecasted }} x_{t}$ equals fixed cost 
Table 1: (Continued)

2. Base case values

Investment $=\$ 100$

Fixed Costs $($ real $)=\$ 10$

Initial revenue net of variable cost (real)

$=X_{1}:$ several values are simulated

Decay rate $($ rea $)=\delta=.04$

Discount rate $($ real $)=r=.06$

Risk-free rate $($ real $)=r_{f}=.02$

Standard deviation $=\sigma=.15$

Inflation rate $=i=0$

3. NPV of pre-tax flows

$$
\text { Assume } X_{1}=29.53 \text { : }
$$

$$
\begin{gathered}
N P V=-100+\sum_{t=1}^{15} \frac{x_{t}}{(1+r)^{t}}-\sum_{t=1}^{15} \frac{F}{\left(1+r_{f}\right)^{t}} \\
N P V=-100+\sum_{t=1}^{15} \frac{29.53(.96)^{t-1}}{(1.06)^{t}}-\sum_{t=1}^{15} \frac{10}{(1.02)^{t}}=0
\end{gathered}
$$


TABLE 2: Project NPUs for base case and sensitivity analysis. BASE CASE (see Table 1)

\begin{tabular}{|c|c|c|c|c|c|}
\hline$\times 1$ & NPU (PC) & NPU (I BM) & NPU (PROJFB) & NPU (PROJC) & NPU (PROJ) \\
\hline $\begin{array}{l}24.00 \\
25.92 \\
27.84 \\
29.76 \\
31.68 \\
33.60 \\
35.52 \\
37.44\end{array}$ & $\begin{array}{r}-42.42 \\
-27.55 \\
-12.68 \\
2.19 \\
17.06 \\
31.93 \\
46.80 \\
61.67\end{array}$ & $\begin{array}{r}-18.03 \\
-10.00 \\
-1.97 \\
6.06 \\
14.09 \\
22.12 \\
30.15 \\
38.18\end{array}$ & $\begin{array}{r}-43.51 \\
-29.71 \\
-16.36 \\
-3.92 \\
7.70 \\
18.23 \\
27.79 \\
36.90\end{array}$ & $\begin{array}{r}-45.84 \\
-32.83 \\
-20.47 \\
-8.77 \\
2.26 \\
\quad 12.68 \\
22.67 \\
32.30\end{array}$ & $\begin{array}{r}-53.44 \\
-41.27 \\
-29.39 \\
-17.80 \\
-6.50 \\
4.50 \\
15.18 \\
25.58\end{array}$ \\
\hline
\end{tabular}

\begin{tabular}{|c|c|c|c|c|c|}
\hline$\times 1$ & $N P V(P C)$ & NPU( I BM) & NPU(PROJFB) & NPU(PROJC) & NPU(PROJ) \\
\hline $\begin{array}{l}24.00 \\
25.92 \\
27.84 \\
29.76 \\
31.68 \\
33.60 \\
35.52 \\
37.44\end{array}$ & $\begin{array}{r}-43.09 \\
-28.27 \\
-13.45 \\
1.37 \\
17.06 \\
31.93 \\
46.80 \\
61.67\end{array}$ & $\begin{array}{r}-18.38 \\
-10.38 \\
-2.38 \\
5.62 \\
14.09 \\
22.12 \\
30.15 \\
38.18\end{array}$ & $\begin{array}{r}-43.09 \\
-28.27 \\
-13.45 \\
1.19 \\
7.70 \\
18.23 \\
27.79 \\
36.90\end{array}$ & $\begin{array}{r}-43.11 \\
-28.50 \\
-14.42 \\
-1.49 \\
2.26 \\
12.68 \\
22.67 \\
32.30\end{array}$ & $\begin{array}{r}-50.41 \\
-38.15 \\
-26.12 \\
-14.27 \\
-6.50 \\
4.50 \\
15.18 \\
25.58\end{array}$ \\
\hline
\end{tabular}

\begin{tabular}{cccccr}
\multicolumn{7}{c}{ STANDARD } & DEUIATION $=0.45$ \\
$\times 1$ & NPU(PC) & NPU(IBM) & NPU(PROJFB) & NPU(PROJC) & NPU(PROJ) \\
\hline 24.00 & -44.49 & -19.14 & -63.14 & -66.55 & -72.08 \\
25.92 & -29.78 & -11.20 & -51.84 & -55.60 & -61.24 \\
27.84 & -15.08 & -3.26 & -40.84 & -44.91 & -50.60 \\
29.76 & -0.37 & 4.68 & -30.68 & -34.42 & -40.13 \\
31.68 & 14.33 & 12.62 & -20.42 & -24.17 & -29.84 \\
33.60 & 29.04 & 20.56 & -10.27 & -14.11 & -19.70 \\
35.52 & 43.74 & 28.50 & -0.34 & -4.22 & -9.71 \\
37.44 & 58.45 & 36.44 & 9.45 & 5.54 & 0.15
\end{tabular}


TABLE 2 (contd.)

\begin{tabular}{|c|c|c|c|c|c|}
\hline$\times 1$ & $N P V(P C)$ & NPU( I BM) & NPU (PROJFB) & NPU(PROJC) & NPU (PROJ) \\
\hline $\begin{array}{l}29.76 \\
33.60 \\
35.52 \\
37.44 \\
39.36 \\
41.28 \\
45.12 \\
48.96 \\
52.80\end{array}$ & $\begin{array}{r}-34.73 \\
-16.87 \\
-7.93 \\
1.00 \\
9.93 \\
18.87 \\
36.73 \\
54.60 \\
72.46\end{array}$ & $\begin{array}{r}-13.87 \\
-4.23 \\
0.60 \\
5.42 \\
10.25 \\
15.07 \\
24.72 \\
34.36 \\
44.01\end{array}$ & $\begin{array}{r}-34.99 \\
-17.98 \\
-10.23 \\
-2.91 \\
3.95 \\
10.45 \\
22.52 \\
33.35 \\
43.70\end{array}$ & $\begin{array}{r}-35.76 \\
-19.60 \\
-11.98 \\
-4.72 \\
2.18 \\
8.73 \\
20.91 \\
32.14 \\
42.74\end{array}$ & $\begin{array}{r}-39.98 \\
-24.68 \\
-17.29 \\
-10.09 \\
-3.08 \\
3.73 \\
16.72 \\
28.86 \\
40.29\end{array}$ \\
\hline
\end{tabular}

PROJECT LIFE $=30$ YEARS (del ta $=0.02)$

\begin{tabular}{|c|c|c|c|c|c|}
\hline$\times 1$ & NPV (PC) & NPV ( I BM) & NPV (PROJFB) & NPV(PROJC) & NPV(PROJ) \\
\hline $\begin{array}{l}24.00 \\
25.92 \\
27.84 \\
29.76 \\
31.68 \\
33.60 \\
35.52 \\
37.44\end{array}$ & $\begin{array}{r}-51.19 \\
-29.41 \\
-7.64 \\
14.13 \\
35.90 \\
57.68 \\
79.45 \\
101.22\end{array}$ & $\begin{array}{r}-22.76 \\
-11.00 \\
0.76 \\
12.51 \\
24.27 \\
36.03 \\
47.79 \\
59.54\end{array}$ & $\begin{array}{r}-56.26 \\
-37.44 \\
-20.24 \\
-3.64 \\
10.94 \\
24.25 \\
36.84 \\
49.36\end{array}$ & $\begin{array}{r}-62.30 \\
-44.97 \\
-28.54 \\
-12.92 \\
2.04 \\
16.48 \\
30.46 \\
44.06\end{array}$ & $\begin{array}{r}-73.00 \\
-56.01 \\
-39.43 \\
-23.29 \\
-7.56 \\
7.79 \\
22.75 \\
37.38\end{array}$ \\
\hline
\end{tabular}




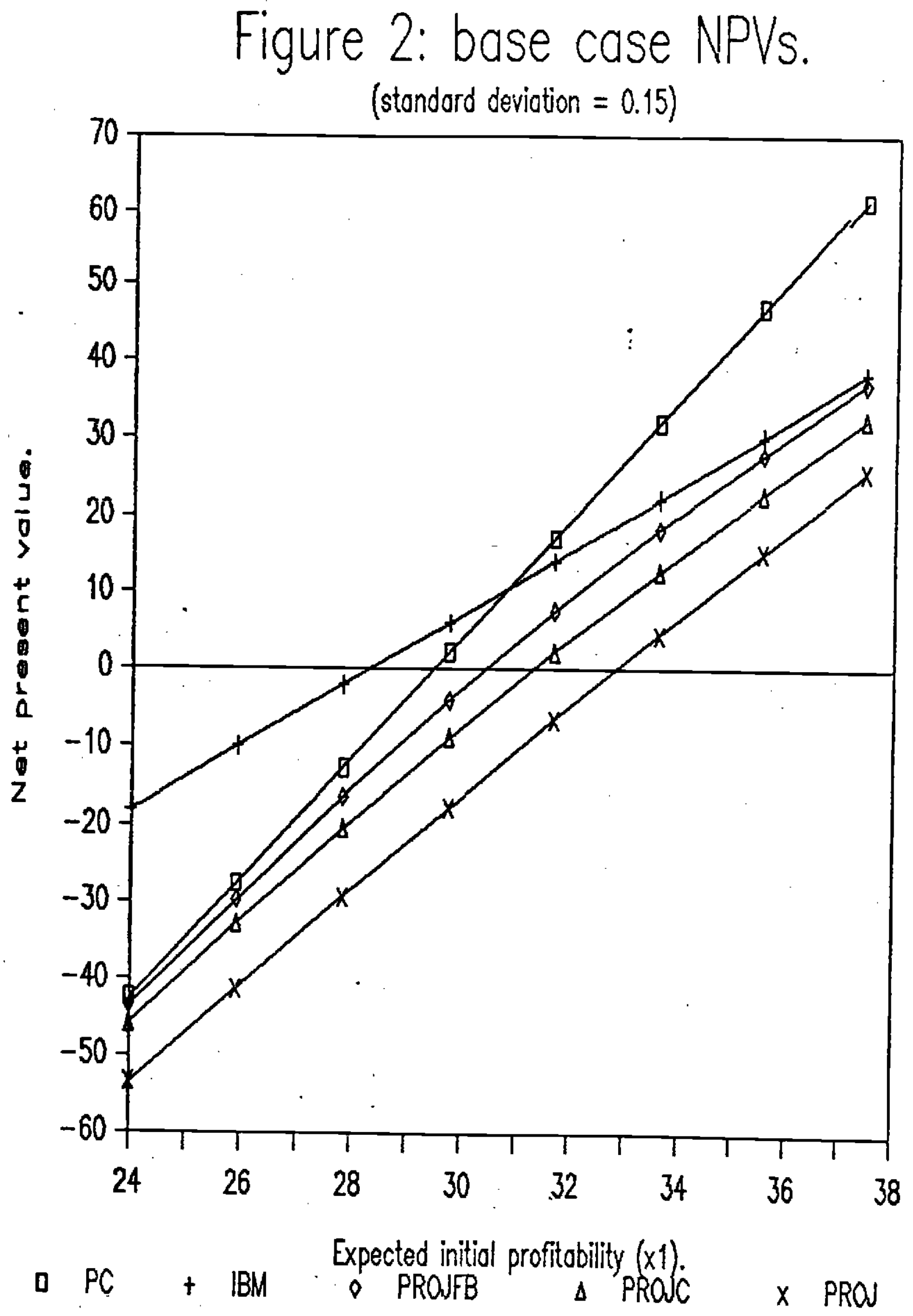




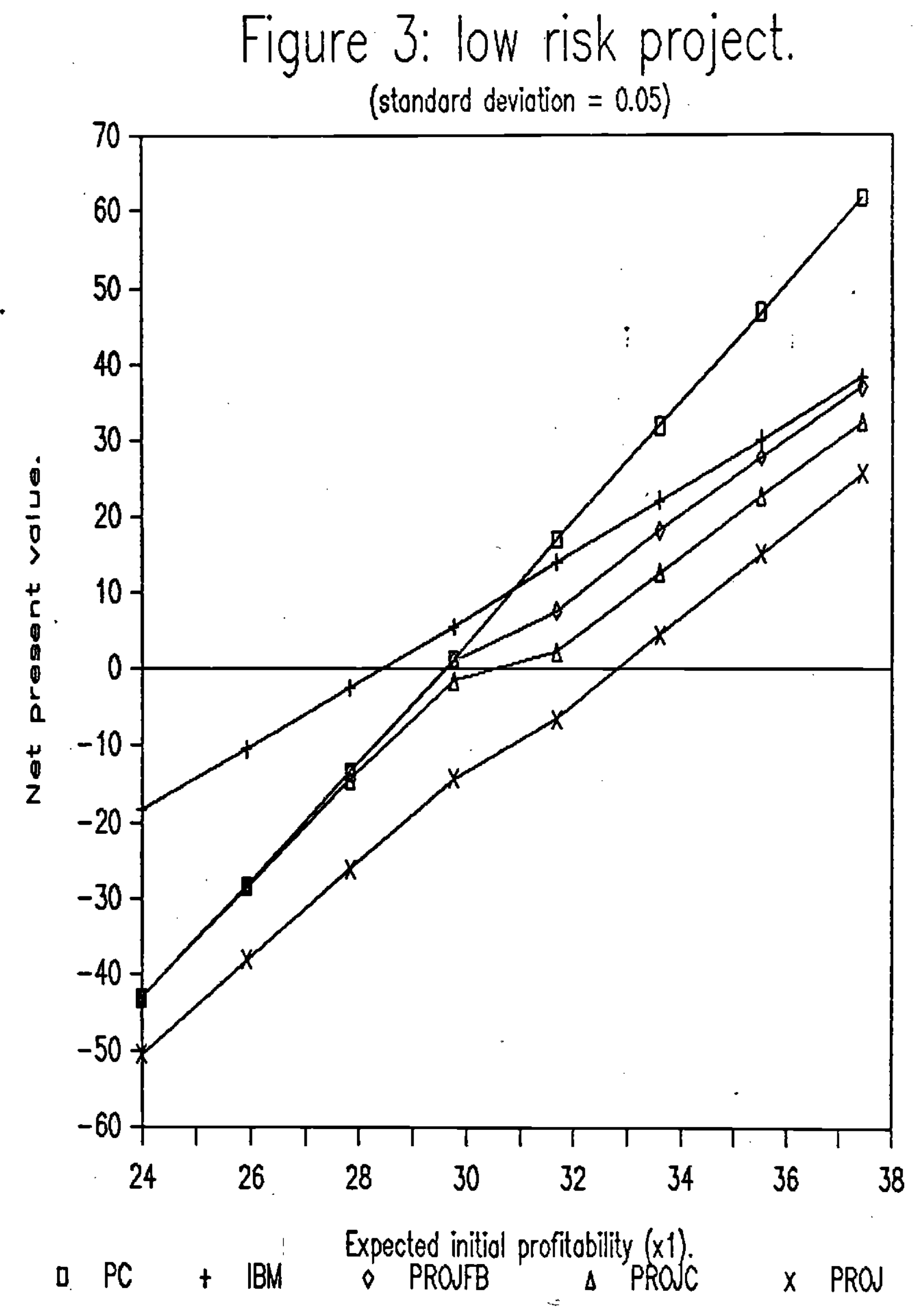




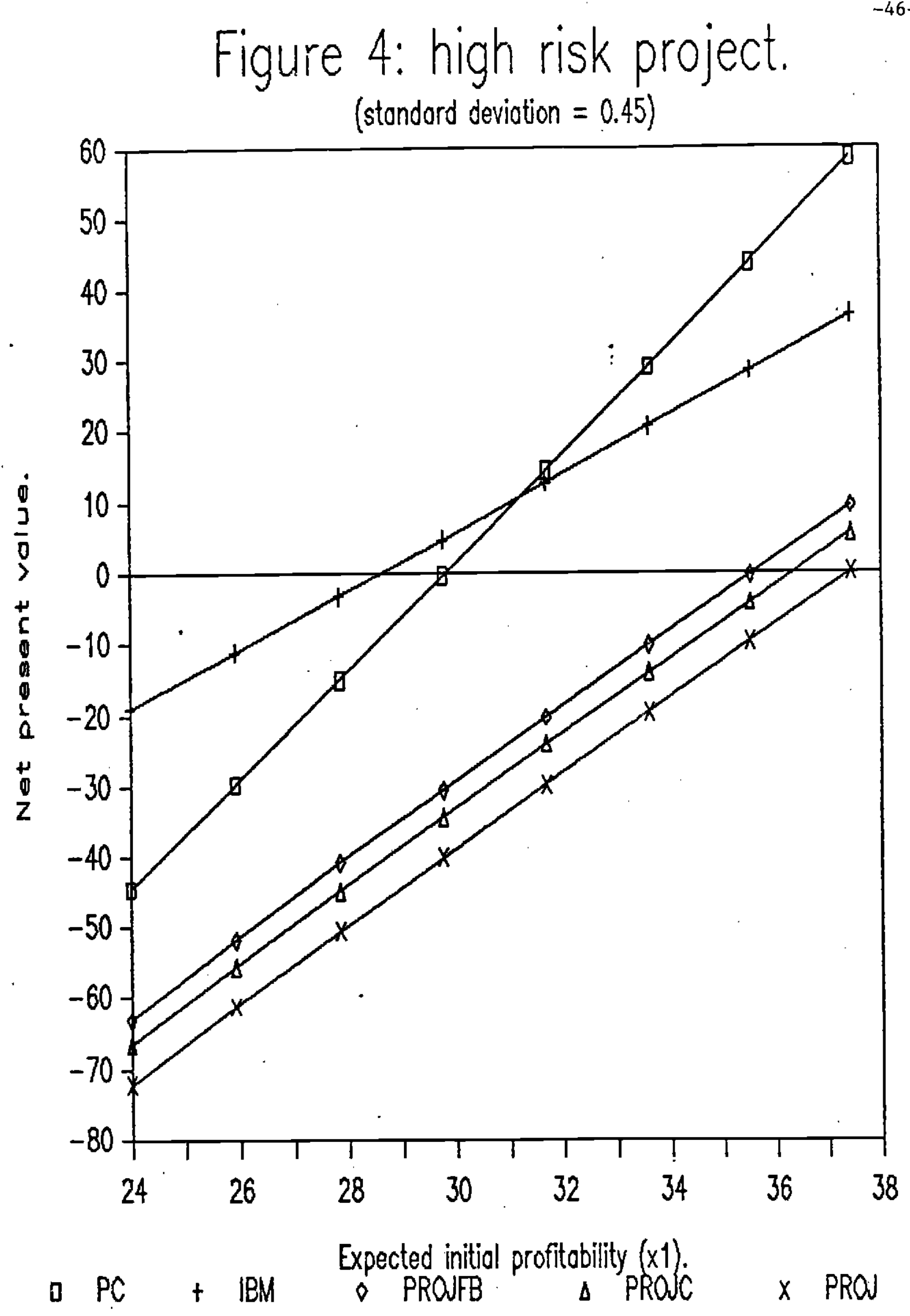


Figure 5: shorter project life. (8 yeors, delto $=0.08)$

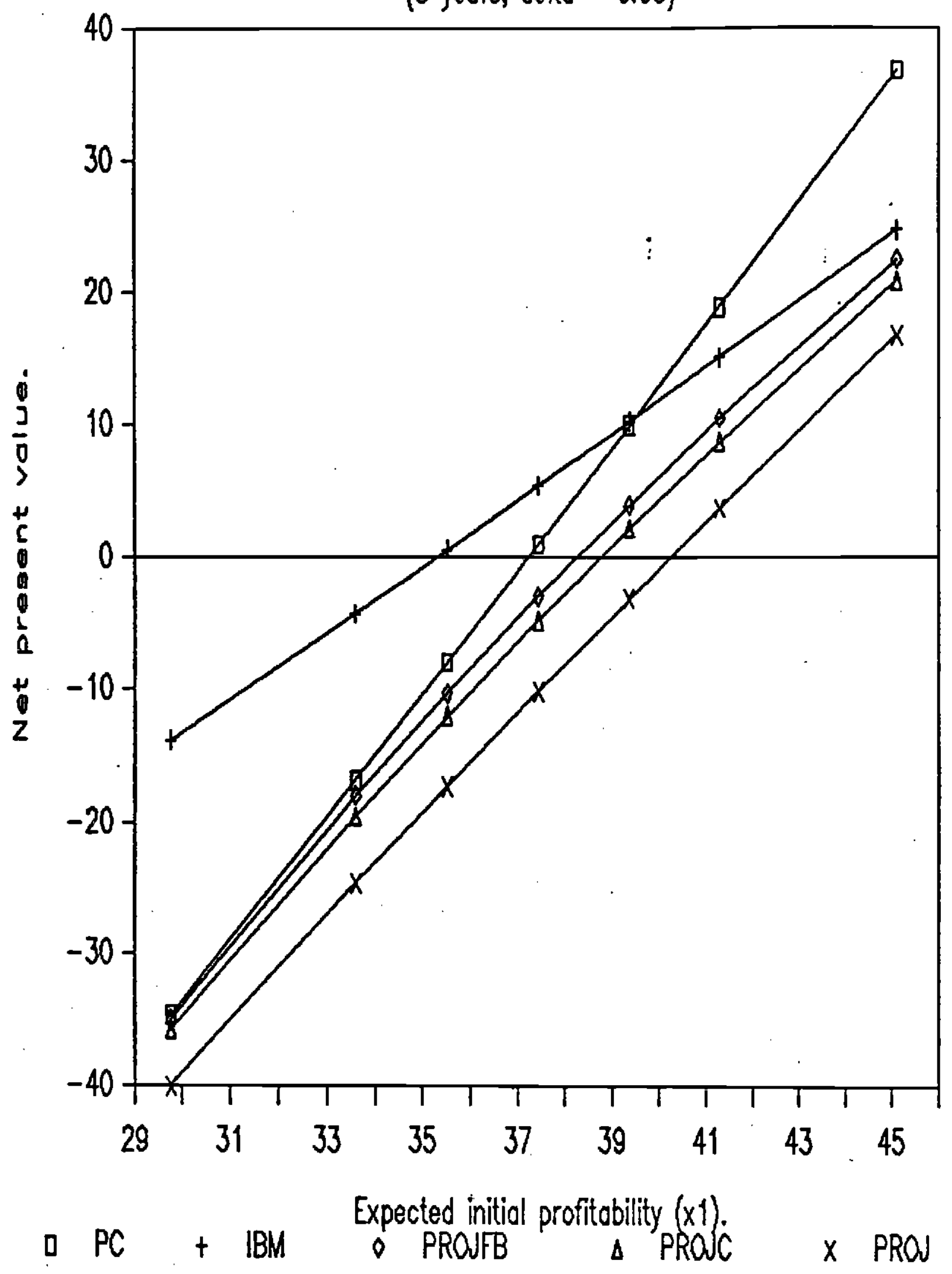




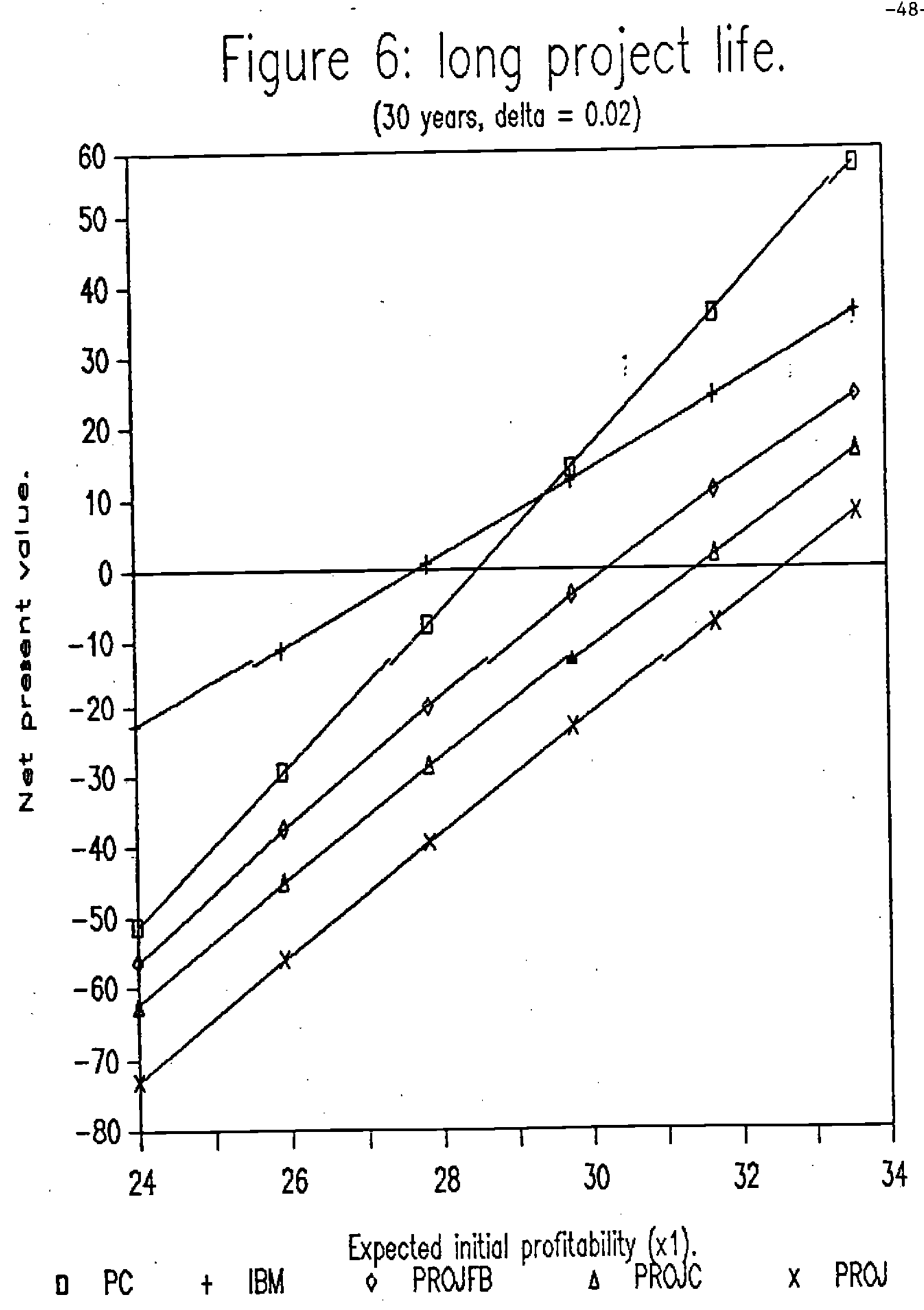




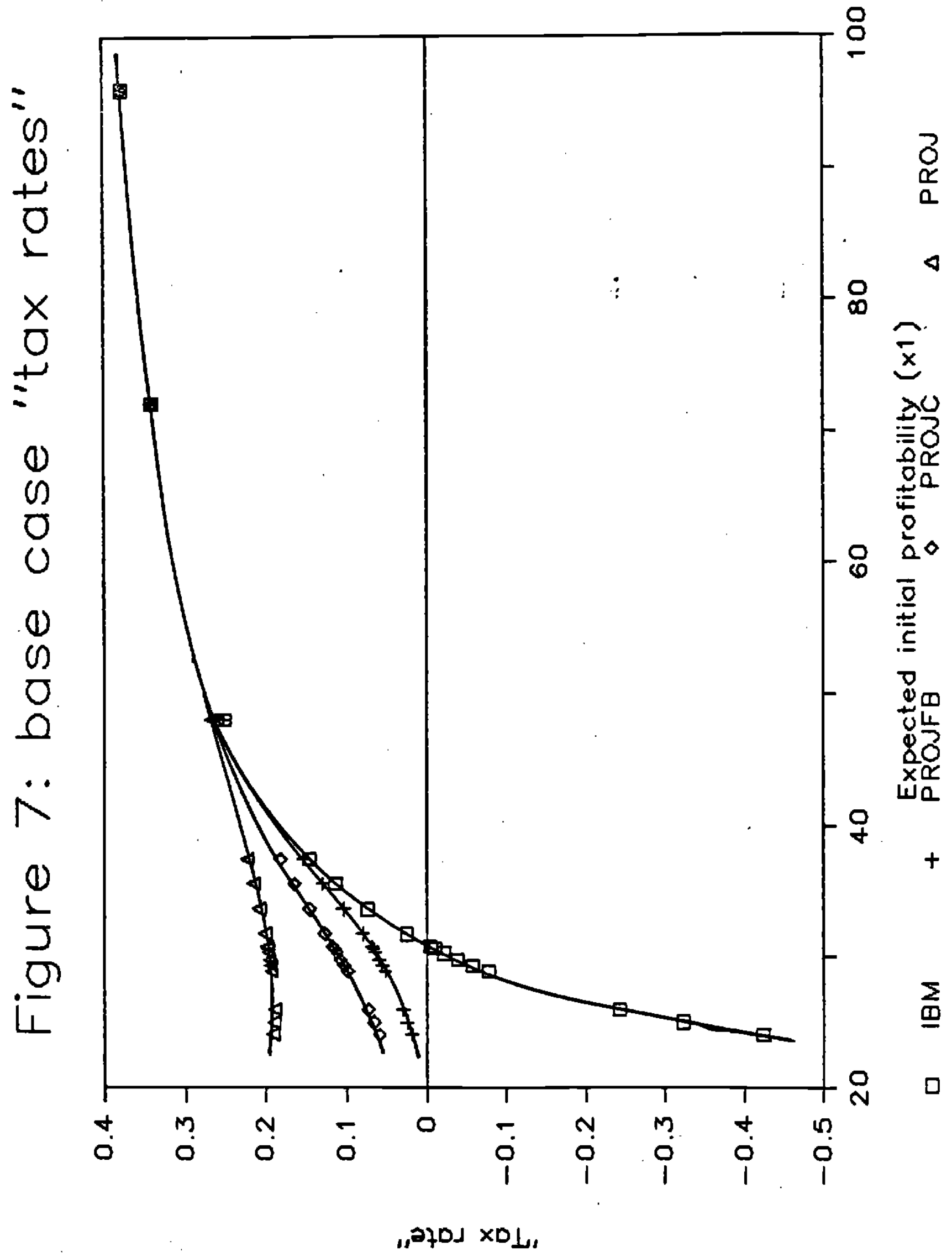


Table 3: The Firm's Existing Assets

Each year the firm invests in a unit that lasts 15 years. Hence in the steady state, the firm consists of 15 units. This table summarizes the characteristics of each unit and gives the basic case values, where appropriate.

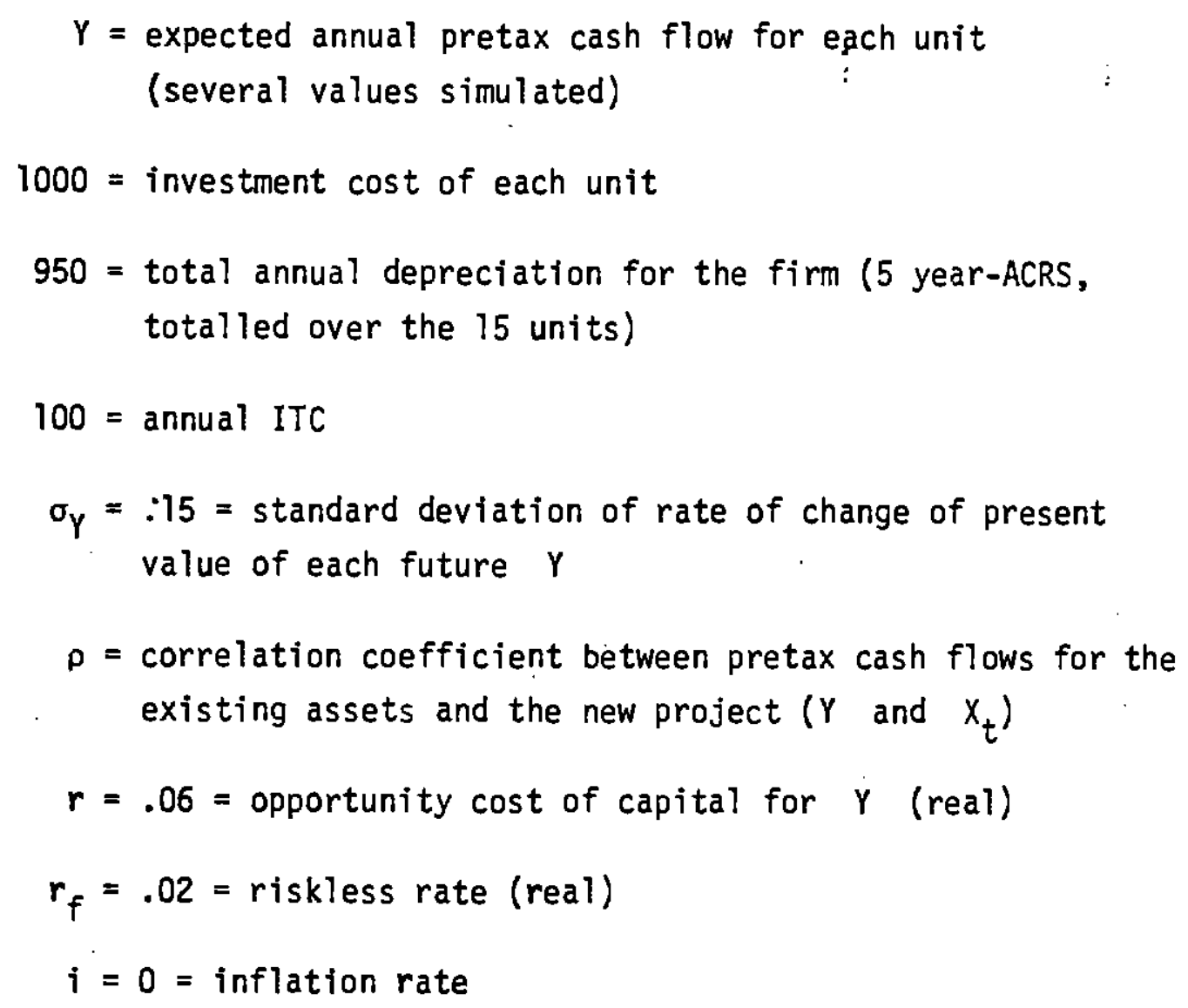


TABL 4: Firm and project combined (see Tables 1 and 3).

\begin{tabular}{|c|c|c|c|c|c|c|}
\hline \multirow[b]{2}{*}{$\times 1$} & \multirow{2}{*}{$\begin{array}{c}\text { NPV } \\
\text { (PROJC) }\end{array}$} & \multicolumn{5}{|c|}{ NPU (COMBINED), correlation $=0$} \\
\hline & & $Y=100$ & $Y=200$ & $Y=1000$ & $Y=5000$ & $Y=10000$ \\
\hline $\begin{array}{r}19.20 \\
28.80 \\
38.40 \\
48.00 \\
57.60 \\
67.20 \\
96.00 \\
960.00\end{array}$ & $\begin{array}{r}-83.49 \\
-18.61 \\
32.99 \\
76.36 \\
116.86 \\
156.56 \\
274.85 \\
3814.81\end{array}$ & $\begin{array}{r}-81.56 \\
-9.74 \\
62.07 \\
133.87 \\
205.77 \\
277.38 \\
492.33 \\
6647.46\end{array}$ & $\begin{array}{r}-50.28 \\
2.77 \\
55.75 \\
108.63 \\
161.41 \\
214.06 \\
371.45 \\
4778.43\end{array}$ & $\begin{array}{r}-39.78 \\
-0.38 \\
39.03 \\
78.43 \\
117.84 \\
157.24 \\
275.44 \\
3819.51\end{array}$ & $\begin{array}{r}-39.74 \\
-0.40 \\
38.93 \\
78.26 \\
117.59 \\
156.93 \\
274.92 \\
3814.81\end{array}$ & $\begin{array}{r}-39.74 \\
-0.40 \\
38.93 \\
78.26 \\
117.59 \\
156.93 \\
274.92 \\
3814.81\end{array}$ \\
\hline
\end{tabular}

\begin{tabular}{|c|c|c|c|c|c|c|}
\hline \multirow[b]{2}{*}{$\times 1$} & \multirow{2}{*}{$\begin{array}{c}\text { NPV } \\
\text { (PROJC) }\end{array}$} & \multicolumn{5}{|c|}{ NPV(COMBINED), correlation $=+0.9$} \\
\hline & & $Y=100$ & $Y=200$ & $Y=1000$ & $Y=5000$ & $Y=10000$ \\
\hline $\begin{array}{r}19.20 \\
30.72 \\
38.40 \\
96.00 \\
960.00\end{array}$ & $\begin{array}{r}-83.50 \\
-7.22 \\
33.36 \\
274.97 \\
3815.98\end{array}$ & $\begin{array}{r}-83.03 \\
2.15 \\
58.88 \\
483.31 \\
6433.81\end{array}$ & $\begin{array}{r}-57.90 \\
2.01 \\
41.89 \\
339.48 \\
4562.77\end{array}$ & $\begin{array}{r}-39.58 \\
7.38 \\
38.86 \\
275.01 \\
3817.08\end{array}$ & $\begin{array}{r}-39.71 \\
7.50 \\
38.98 \\
275.04 \\
3815.98\end{array}$ & $\begin{array}{r}-39.71 \\
7.50 \\
38.98 \\
275.04 \\
3815.98\end{array}$ \\
\hline
\end{tabular}

\begin{tabular}{|c|c|c|c|c|c|c|}
\hline \multirow[b]{2}{*}{$\times 1$} & \multirow{2}{*}{$\begin{array}{c}\text { NPV } \\
\text { (PROJC) }\end{array}$} & \multicolumn{5}{|c|}{ NPU(COMBINED), correlation $=-0.9$} \\
\hline & & $Y=100$ & $Y=200$ & $Y=1000$ & $Y=5000$ & $Y=10000$ \\
\hline $\begin{array}{r}19.20 \\
30.72 \\
38.40 \\
96.00 \\
960.00\end{array}$ & $\begin{array}{r}-82.71 \\
-6.61 \\
33.95 \\
277.32 \\
3839.56\end{array}$ & $\begin{array}{r}-79.84 \\
7.56 \\
65.82 \\
502.44 \\
6900.70\end{array}$ & $\begin{array}{r}-42.55 \\
24.56 \\
69.24 \\
402.31 \\
5049.51\end{array}$ & $\begin{array}{r}38.93 \\
8.87 \\
40.73 \\
279.60 \\
3848.21\end{array}$ & $\begin{array}{r}-39.24 \\
8.25 \\
39.92 \\
277.40 \\
3839.56\end{array}$ & $\begin{array}{r}-39.24 \\
8.25 \\
39.92 \\
277.40 \\
3839.56\end{array}$ \\
\hline
\end{tabular}


Figure 8: incremental value of project

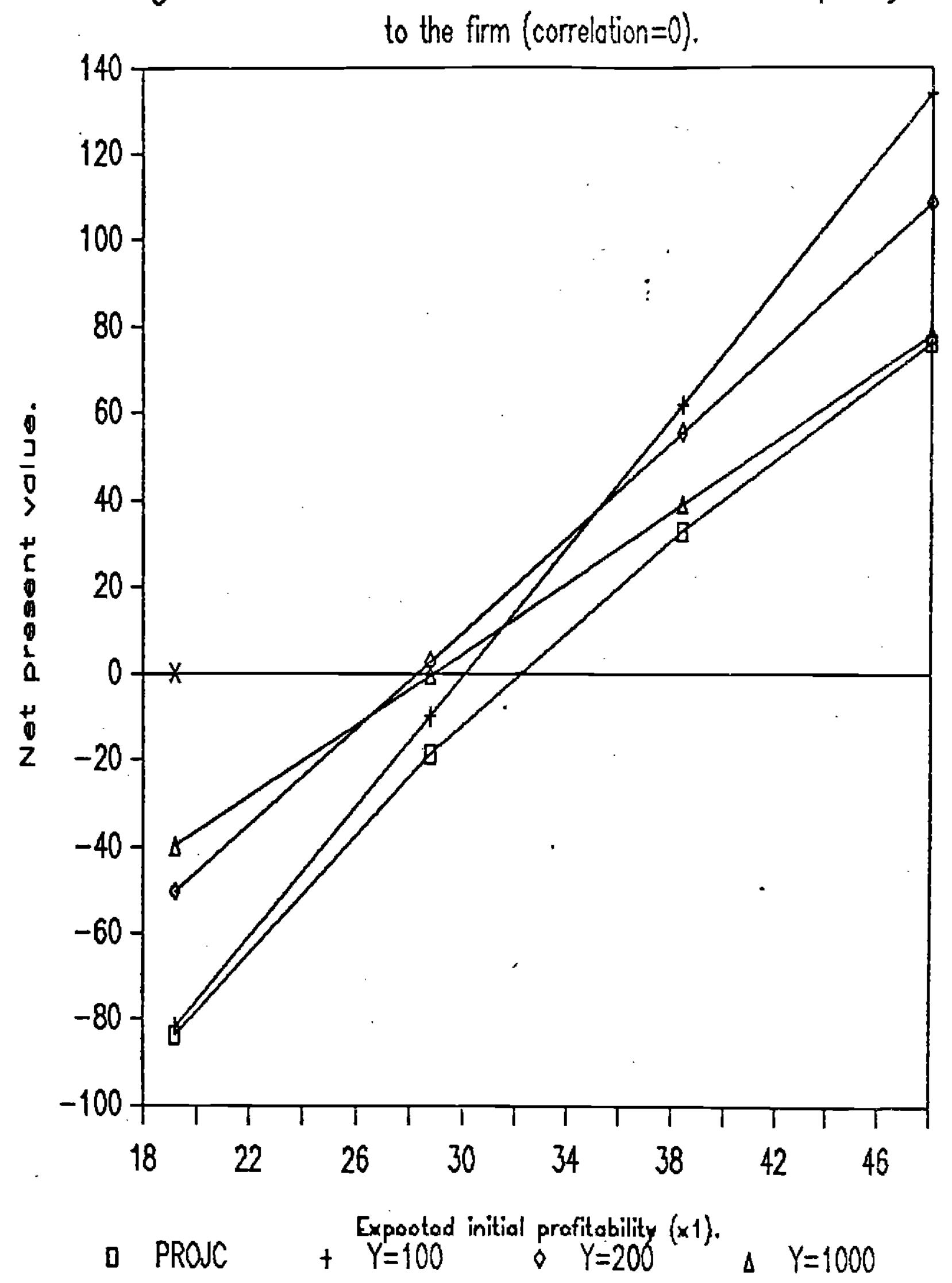


Table 5: Firm and Project Combined

$$
\left(x_{1}=38.40, \sigma_{X}=\sigma_{Y}=0.45, \operatorname{NPV}(\text { PROUC }) \simeq 6.52\right)
$$

\begin{tabular}{cccc}
\multicolumn{5}{c}{$\underline{\text { NPV(COMBINED) }}$} & \\
$\rho$ & $\underline{Y=100}$ & $\underline{1000}$ & $\underline{5000}$ \\
+0.9 & 21.08 & 27.98 & $\vdots$ \\
+0.6 & 33.17 & 29.30 & 37.15 \\
+0.3 & 45.16 & 37.21 & 34.52 \\
0 & 55.96 & 49.13 & 40.41 \\
-0.3 & 66.80 & 62.26 & 47.20 \\
-0.6 & 76.60 & 77.15 & 60.12 \\
-0.9 & 87.40 & 93.41 & 73.84
\end{tabular}

